\title{
QUALITY OF RAINWATERS OUTFLOWING FROM ROOFS OF GARAGE BUILDINGS OF PARK AUTHORITY OF ROZTOCZE NATIONAL PARK
}

\author{
Krzysztof Jóźwiakowski', Agnieszka Listosz', Magdalena Gizińska-Górna', Aneta Pytka', \\ Michał Marzec ${ }^{1}$, Bożena Sosnowska ${ }^{2}$, Monika Chołody ${ }^{3}$, Agnieszka Dyczko ${ }^{4}$
}

1 Department of Environmental Engineering and Geodesy, University of Life Sciences in Lublin, Leszczyńskiego St. 7, 20-069 Lublin, Poland, e-mail: krzysztof.jozwiakowski@up.lublin.pl, agnieszka.listosz@up.lublin.pl, madziagizinska@tlen.pl, anetapytka@poczta.fm,michal.marzec@up.lublin.pl

2 Department of Biotechnology, Human Nutrition and Food Commodities, University of Life Sciences in Lublin, Skromna St. 8, 20-704 Lublin, Poland, e-mail: bozena.sosnowska@up.lublin.pl

${ }_{3}$ Art.-Bruk Monika Chołody, Miłocin 40a, 24-150 Miłocin, e-mail: monikacholody@wp.pl

${ }^{4}$ Water and Wastewater Management Students' Scientific Team, University of Life Sciences in Lublin, Leszczyńskiego St. 7, 20-069 Lublin, Poland, e-mail: agnieszkadyczko@gmail.com

Received: 2016.08.01 Accepted: 2016.09 .26 Published: 2016.11.01

\begin{abstract}
Rational use of surface and underground waters leads to a reduction in their consumption, which is currently one of the fundamental tasks in the field of the conservation of waters, in its broad sense. This includes also the utilisation of water from additional sources, such as e.g. precipitation water. The paper presents an analysis of the quality of rainwater outflowing from the roofs of garage buildings of the Park Authority of the Roztocze National Park. The results of analyses presented in the paper indicate a favourable composition of rainwater that meets the norms defined for water for human consumption. In the waters under analysis, exceeded levels were noted for ammonia, manganese and biological factors, but these do not preclude the use of the waters for household purposes. Rainwaters at the Roztocze National Park can be used for car washing, for the irrigation of green areas, or for toilet flushing. Such utilisation of rainwaters can largely contribute to a reduction of the use of high-quality underground waters.
\end{abstract}

Keywords: quality of waters, rainwaters, water utilisation, Roztocze National Park,

\section{INTRODUCTION}

Water is the fundamental element of life, necessary and irreplaceable for humanity and for the entire living world. It is used as a source and a factor of economic growth and wellbeing, and it is also a fundamental natural element of ecosystems and climate regulation [Komisja Europejska (European Commission) 2011]. Both the amount and the quality of water resources are of key importance for human health and for the development of all sectors of the economy, due to which water becomes a factor determining the living standard of the population. The demand for water increases with the development of civilisation. The increase of water consumption due to human activity and the constantly growing contamination of sources of water intake, especially of surface waters, cause a deterioration of water situation all over the world.

Poland is one of the group of countries with the lowest water resources in Europe. This is due to unfavourable climate and hydrological conditions. In the years 2000-2014, the average annual outflow of surface waters from the territory of Poland, including with the inflow from neighbouring countries, amounted to 61.2 $\mathrm{km}^{3}$. The annual water resources per 1 inhabitant in Poland are less than $1600 \mathrm{~m}^{3}$, while in most European countries they oscillate at the level of nearly $5000 \mathrm{~m}^{3}$ per 1 inhabitant [GUS (Central Statistical Office) 2015]. 
Problems related with the creation and protection of water resources, and their management, are the effect of the spatial-temporal variation of atmospheric precipitations, and of the condition of the water mains-sewerage infrastructure. Atmospheric precipitations are the primary element of water balance, ensuring the renewal of surface and underground water resources. Therefore, rainwaters should be protected against contamination, and managed and utilised at the site of appearance [Królikowska, Królikowski 2012].

The totals of atmospheric precipitations in particular months and years, as well as their spatial distribution over the territory of Poland, are characterised by enormous variation. According to the Central Statistical Office data [GUS 2015], the lowest annual sums of precipitations in 2014 were noted in North, North-Western and Central Poland (below $600 \mathrm{~mm}$ ), considerably higher precipitation totals were noted in East Poland, and the highest - in South Poland (above $1300 \mathrm{~mm}$ ), in the area of Zakopane.

The Act on Water Law [J. of Laws 2001, No. 11, item 1229] and the Act on the Environment Protection Law [J. of Laws 2001, No. 62, item 627] introduce a definition of rainwaters which are defined as precipitation or thaw waters, collected in open or closed sewerage systems, originating from contaminated areas with permanent surfacing, and in particular from urban areas, ports, airports, industrial, commercial, service and storage areas, from transportation depots and from roads and car parks. According to the above definition, rain and rainwaters that come from roofs are not considered as wastewaters, and therefore can be drained to waters and soils without purification, and can also be used for economic purposes (irrigation of green areas, car washing, toilet flushing).

Rainwaters from roofs are notably less contaminated than rainwaters from hardened surfaces, but in the course of a rainfall unfavourable changes take place in water quality, due to its contact with contaminants contained in the air [Rybicki, Rybicki 2001; Niemiec 2012; Mańkowska-Wróbel 2014]. Research shows that rainwaters have at least the same parameters as water approved by the European Union for use in swimming pools. They are characterised by a low level of bacteriological contamination, contains weak solutions of acids, but has no content of compounds that would case its hardness (calcium and magnesium). The quality of precipitation water disqualifies it as drinking water, but does not preclude its use for household and industrial purposes [Skwarzyńska et al. 2014a].

The objective of the study was the estimation of the quality of rainwaters drained from the roofs of two garage buildings of the Park Authority of the Roztocze National Park in the context of determination of a method of utilisation of the waters for the needs of the Park Authority.

\section{MATERIALS AND METHODS}

The study was conducted in Zwierzyniec, in the area of the Roztocze National Park (RNP), analysing the quality of rainwaters collected from the roofs of two buildings at the Park Authority. One of the buildings is used as a garage, and the other as a garage-workshop building (Photo 1). The garage building has dimensions of $24.6 \times 6.5 \mathrm{~m}$, roof area in projection onto the hori-

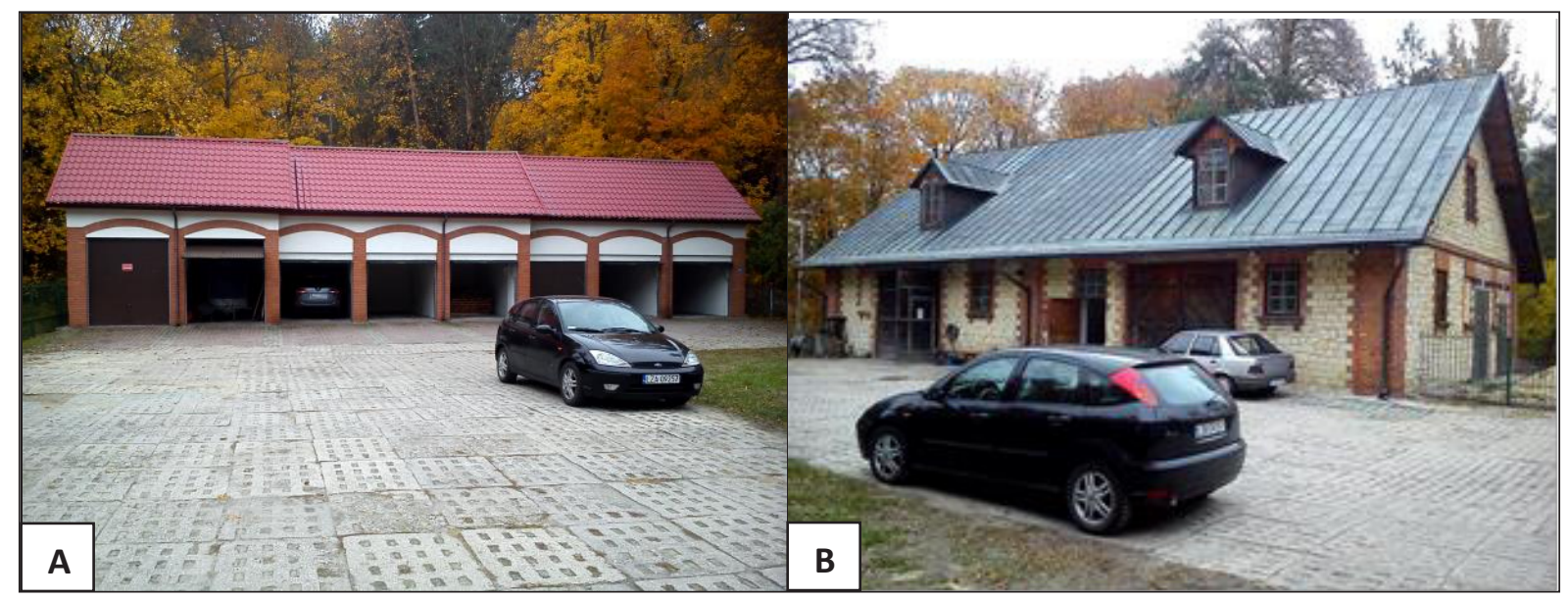

Photo 1. Garage building (A) and garage-workshop building (B) at the Park Authority, RNP (photo M. Marzec) 
zontal plane of about $185 \mathrm{~m}^{2}$, and roof slope angle of $40^{\circ}$. The dimensions of the garage-workshop building are $21 \times 12.4 \mathrm{~m}$, with $302 \mathrm{~m}^{2}$, and slope of $37^{\circ}$. Both buildings have metal roofing with gutter systems [Jóźwiakowski et al. 2013].

In 2014, for the buildings at the Park Authority, RNP, a system was built for the accumulation and utilisation of rainwaters, composed of two tanks with capacity of $10 \mathrm{~m}^{3}$ each, and a pumping system (Fig. 1).

In the buildings of the Park Authority water is used mainly for toilet flushing, personal hygiene and for care and maintenance work in the buildings and in their surroundings. Some water is also used for washing the Park Authority vehicles. Before the system of precipitation water management was built, the demand for water in all the buildings of the Park Authority was fully covered from the water intake of the brewery in
Zwierzyniec. Waters taken from that intake (120 $\mathrm{m}$ ) belong to the main aquiferous layer of Cretaceous waters, so-called Roztocze aquifer [http:// roztoczanskipn.pl/pl/]. Those are waters of very good quality, and their use for economic purposes can be viewed as a waste of valuable resources of the environment, therefore the use of rainwaters is a beneficial alternative.

In recent years, in the area of the RNP an increase is observed in the annual precipitation totals, which creates favourable conditions for the use of rainwaters for economic purposes. The sums of precipitations in the area of the RNP and their spatial distribution are characterised by notable variability, related with the land relief. During the multi-year period of 1998-2012 the annual sums of precipitations varied from $602 \mathrm{~mm}$ to $889 \mathrm{~mm}$, with an average value of $734 \mathrm{~mm}$ (Fig. 2).

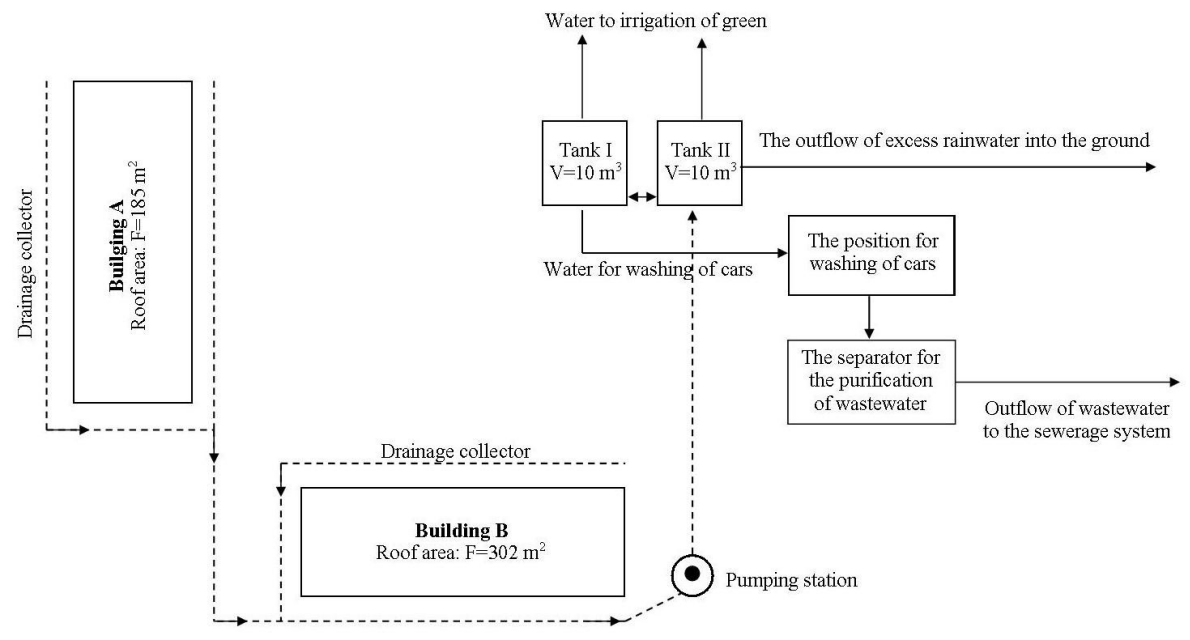

Figure 1. Schematic of the system of rainwater management at Park Authority, RNP [Jóźwiakowski et al. 2013]

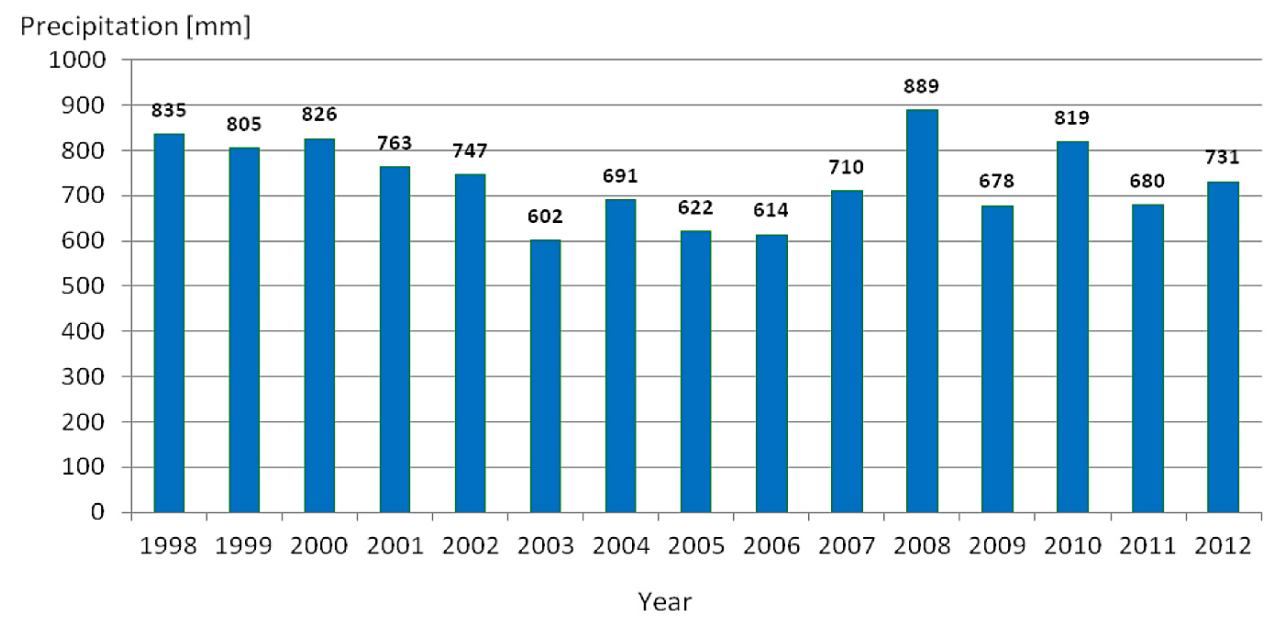

Figure 2. Annual sums of atmospheric precipitations at the Base Station of Integrated Monitoring of Natural Environment Roztocze in 1998-2012 (source: RNP data) 
The highest monthly sums of precipitations, above $50 \mathrm{~mm}$, occur in the RNP in the spring (April, May, June) and in the summer (July, August, September). The maximum sums of precipitations are noted in July - average of $112 \mathrm{~mm}$ (Fig. 3). The presented data indicate that the largest amounts of rainwaters can be accumulated in the period of the highest demand for them.

According to the estimations by Jóźwiakowski et al. [2013], the potential amount of rainwaters flowing off the roofs of the garage buildings at the Park Authority of the RNP in almost all the months of the year exceeds the demand for water for economic purposes, such as vehicle washing and irrigation of green areas.

Samples of rainwaters for the quality analyses were taken in February, June, September and November, 2015, at three points of the system for precipitation water management: 1 - pumping station, 2 - tank I, 3 - tank II (Fig. $3)$. The parameters assayed in the water samples included $\mathrm{pH}$, concentration of dissolved oxygen, electrolytic conductivity, concentration of ammonia, nitrates, nitrites, sulphates, chlorides, iron, potassium, phosphates and manganese. The physicochemical analyses of the waters were conducted with the use of methods commonly applied [Hermanowicz et al. 1999]. Based on the results obtained, characteristic index values and standard deviations were determined. In addition, the numbers of coliform bacteria, faecal coliform bacteria, as well as the numbers of mesophilic and psychrophilic bacteria cells in the water sample were determined in accordance with the methods described on the Polish Standards [PN-C04615-05:1975P; PN-C-04615-07:1977P; PN-ISO 6222:1999].

The physicochemical analyses were performed at the Laboratory of Water and Wastewater Analysis, Department of Environmental Engineering and Geodesy, University of Life Sciences in Lublin. The microbiological parameters were assayed at the Laboratory of Ecological Food of Plant Origin, Department of Biotechnology, Human Nutrition and Food Commodities, University of Life Sciences in Lublin.

The quality of the rainwaters was compared with the requirements defined in the Regulation of the Minister of Health on the quality of water for human consumption [J. of Laws 2007 No. 61, item 417] and in amending Act [J. of Laws 2010 No. 72, item 466].

\section{RESULTS AND DISCUSION}

Based on the study is can be stated that rainwaters collected from the roofs of the garage buildings at the Park Authority, RNP, are characterised by good quality.

The analysed water had alkaline reaction. There was only a single case of exceeding, though only slightly, the permissible value of $\mathrm{pH}$ for

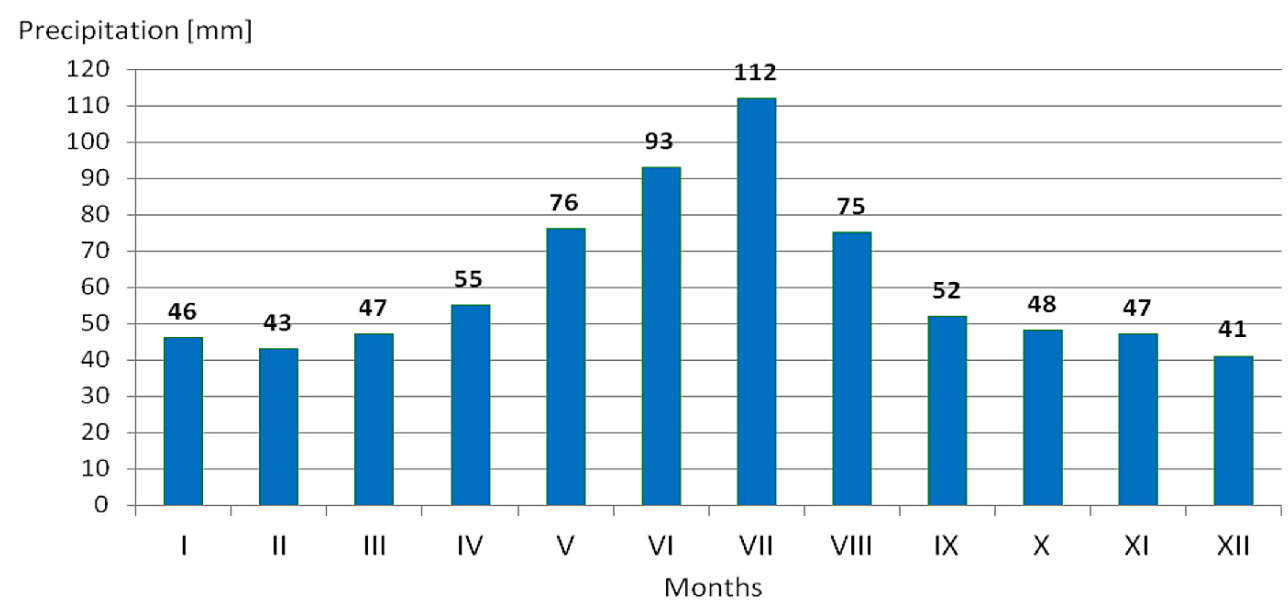

Figure 3. Mean monthly sums of atmospheric precipitations at the Base Station of Integrated Monitoring of Natural Environment Roztocze in 1998-2012 (source: RNP data) 
potable water, defined in the Regulations of the Minister of Health [J. of Laws 2007 No. 61, item 417; J. of Laws 2010 No. 72, item 466], at the level of 6.5-9.5. Nevertheless the values noted in the analyses should be considered as high compared to values given in the literature [Ociepa et al. 2010; Skwarzyńska et al. 2014a; Skwarzyńska et al. 2014b]. As a rule, the reaction of rainwaters is neutral, but during the contact of rain water with acid-forming substances (carbon dioxide, nitric oxide) it can assume a slightly acidic character. An alkalising factor can be industrial dust contaminants, suspended in atmospheric air or deposited on the run-off surface [Molenda 2006; Królikowska, Królikowski 2012]. Within the area of the RNP there are no potential industrial sources, but household stoves can play a significant role in air pollution. An additional factor determining increased $\mathrm{pH}$ of the analysed rainwaters can be contamination with bird droppings, washed off the roof surfaces. They contain notable amounts of alkaline components, e.g. potassium, calcium and magnesium oxides, and nitrogen, mainly in the form of uric acid which easily undergoes ammonification, causing additional alkalisation of the water [Mazur, Wojtas 1983].

The highest value of electrolytic conductivity was noted at the pumping station, in February $-275 \mu \mathrm{S} \cdot \mathrm{cm}^{-1}$, and the lowest in tank II - in June $-41 \mu \mathrm{S} \cdot \mathrm{cm}^{-1}$ (Table 1). The results obtained are considerably lower than the limit value of $2500 \mu \mathrm{S} \cdot \mathrm{cm}^{-1}$.

The good quality of the analysed rainwaters is evidenced also by the low content of nitrates, nitrites, chlorides and sulphates. Noted concentrations of $\mathrm{NO}_{3}$ and $\mathrm{NO}_{2}$, as well as of $\mathrm{SO}_{4}$ and $\mathrm{Cl}$, were significantly lower than the permissible levels of those parameters in drinking water. Also low were the levels of iron $(\mathrm{Fe})$ and potassium $(\mathrm{K})$, and the content of phosphates. Only at sampling point 1 , in November, the level of $0.33 \mathrm{mg} \mathrm{Fe} \cdot \mathrm{dm}^{-3}$ was noted (Table. 1), while the limit level of that element for drinking water is $0.2 \mathrm{mg} \mathrm{Fe} \cdot \mathrm{dm}^{-3}$. Potassium concentrations in the analysed waters varied from $9.2 \mathrm{mg}$ $\mathrm{K} \cdot \mathrm{dm}^{-3}$ in September to $22.1 \mathrm{mg} \mathrm{K} \cdot \mathrm{dm}^{-3}$ in February. For most of the indices, the analysed rainwaters display better quality than that given by Skwarzyńska et al. [2014a, 2014b].

The chemical indicator that disqualified to the greatest extent the rainwaters collected from the garage buildings at the Park Authority was ammonia. In all analysed samples its content oscillated in the range from 0.54 to $1.09 \mathrm{mg} \mathrm{NH}_{4} \cdot \mathrm{dm}^{-3}$ (Table 1). According to the Regulations of the Minister of Health [J. of Laws 2007 No. 61, item 417; J. of Laws 2010 No. 72, item 466] permissible concentration of ammonia in drinking water is $0.50 \mathrm{mg} \mathrm{NH}{ }_{4} \mathrm{dm}^{-3}$. Its elevated level in the rainwaters may be a result of bird droppings washing off the roof surfaces by rainwaters [WojtyłaBuciora, Marcinkowski 2010]. As already mentioned, bird droppings contain large amounts of organic forms of nitrogen, mainly uric acid and urea, that under favourable conditions transform into ammonium forms.

Manganese content is a parameter that has a negative effect on water quality. Its elevated

Table 1. Physicochemical properties of rainwaters collected from roofs of garage buildings at Park Authority, RNP

\begin{tabular}{|c|c|c|c|c|c|c|c|c|c|c|c|c|c|}
\hline \multirow{3}{*}{ Parameter } & \multicolumn{12}{|c|}{ Sampling points } & \multirow{3}{*}{ Limit values * } \\
\hline & \multicolumn{4}{|c|}{1} & \multicolumn{4}{|c|}{2} & \multicolumn{4}{|c|}{3} & \\
\hline & $\min$ & $\max$ & $\bar{x}$ & 6 & $\min$ & $\max$ & $\bar{x}$ & 6 & $\min$ & $\max$ & $\bar{x}$ & б & \\
\hline $\mathrm{pH}$ & 7.75 & 9.47 & 8.58 & 0.74 & 8.57 & 9.27 & 9.07 & 0.34 & 8.72 & 9.59 & 9.22 & 0.38 & $6.5-9.5$ \\
\hline $\begin{array}{l}\text { Dissolved oxygen } \\
{\left[\mathrm{mg} \mathrm{O}_{2} \cdot \mathrm{dm}^{-3}\right]}\end{array}$ & 4.30 & 10.45 & 6.60 & 2.73 & 3.87 & 11.41 & 7.49 & 3.90 & 4.08 & 11.05 & 7.44 & 3.70 & - \\
\hline Conductivity $\left[\mu \mathrm{S} \cdot \mathrm{cm}^{-1}\right]$ & 51 & 275 & 122 & 103 & 42 & 85 & 62 & 19 & 41 & 86 & 63 & 20 & 2500 \\
\hline $\mathrm{NH}_{4}\left[\mathrm{mg} \mathrm{NH}_{4} \cdot \mathrm{dm}^{-3}\right]$ & 0.78 & 1.09 & 0.94 & 0.13 & 0.54 & 1.00 & 0.76 & 0.21 & 0.54 & 0.97 & 0.73 & 0.23 & 0.5 \\
\hline $\mathrm{NO}_{3}\left[\mathrm{mg} \mathrm{NO}_{3} \cdot \mathrm{dm}^{-3}\right]$ & 0.62 & 2.55 & 1.52 & 0.83 & 0.86 & 2.14 & 1.54 & 0.56 & 0.69 & 1.78 & 1.10 & 0.48 & 50 \\
\hline $\mathrm{NO}_{2}\left[\mathrm{mg} \mathrm{NO}_{2} \cdot \mathrm{dm}^{-3}\right]$ & 0.12 & 0.30 & 0.22 & 0.07 & 0.06 & 0.24 & 0.15 & 0.07 & 0.05 & 0.21 & 0.13 & 0.07 & 0.5 \\
\hline $\mathrm{SO}_{4}\left[\mathrm{mg} \mathrm{SO}_{4} \cdot \mathrm{dm}^{-3}\right]$ & 3.00 & 25.00 & 14.50 & 10.25 & 2.00 & 4.00 & 2.75 & 0.96 & 4.00 & 43.00 & 17.67 & 21.96 & 250 \\
\hline $\mathrm{Cl}\left[\mathrm{mg} \mathrm{Cl} \cdot \mathrm{dm}^{-3}\right]$ & 0.80 & 3.10 & 1.63 & 1.01 & 0.80 & 1.20 & 0.95 & 0.19 & 0.60 & 1.40 & 0.93 & 0.34 & 250 \\
\hline $\mathrm{Fe}\left[\mathrm{mg} \mathrm{Fe} \cdot \mathrm{dm}^{-3}\right]$ & 0.13 & 0.33 & 0.21 & 0.09 & 0.09 & 0.13 & 0.11 & 0.02 & 0.09 & 0.12 & 0.11 & 0.02 & 0.2 \\
\hline 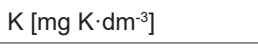 & 10.85 & 18.46 & 13.46 & 3.46 & 9.20 & 22.12 & 13.23 & 6.07 & 9.44 & 20.64 & 14.71 & 5.18 & - \\
\hline $\mathrm{PO}_{4}\left[\mathrm{mg} \mathrm{PO}_{4} \cdot \mathrm{dm}^{-3}\right]$ & 0.07 & 0.31 & 0.19 & 0.10 & 0.06 & 1.08 & 0.33 & 0.50 & 0.02 & 0.77 & 0.33 & 0.32 & - \\
\hline $\mathrm{Mn}\left[\mathrm{mg} \mathrm{Mn} \cdot \mathrm{dm}^{-3}\right]$ & 0.30 & 0.30 & 0.30 & 0.00 & 0.20 & 0.40 & 0.30 & 0.10 & 0.20 & 0.40 & 0.30 & 0.10 & 0.05 \\
\hline
\end{tabular}

* according to [J. of Laws 2007 No. 61, item 417; J. of Laws 2010 No. 72, item 466] 
content in water causes technological problems in water supply systems, bitter taste of the water, and its coloration [Tekerlekopoulou, Vayenas 2008; Gouzinis et al. 1998; Funes et al. 2014]. At excessive concentrations, that element has toxic effects on the human organism [Donaldson 1987; Takeda 2003]. In all analysed samples of rainwaters the content of manganese was excessive and varied from 0.2 to $0.4 \mathrm{mg} \mathrm{Mn} \cdot \mathrm{dm}^{-3}$ (Table 1).

The microbiological status of water is a highly important factor from the viewpoint of human health. Microbiological analyses of rainwaters from the roofs of garage buildings at the Park Authority, RNP, revealed that their quality is poor. The basic parameter taking into account in the estimation of the sanitary status of waters is the content of coliform bacteria. Those bacteria are among the indicator microorganisms, constituting natural intestinal microflora of humans and thermophilic animals. According to the Regulations of the Minister of Health, no presence of coliform bacteria is permitted in drinking water [J. of Laws 2007 No. 61, item 417; J. of Laws 2010 No. 72, item 466]. In terms of the presence of coliform bacteria, almost all of the analysed samples did not meet that requirement. The sole exception was the water sampled in February in both tanks. The numbers of coliforms varied from 0 do $7 \cdot 10^{3}$ MPN $\cdot 100 \mathrm{~cm}^{-3}$ (Table 2).

Contamination with faecal coliforms was found in $25 \%$ of the analysed samples. The highest numbers of bacteria from that group were noted in June in tank II $-7 \cdot 10^{3} \mathrm{MPN} \cdot 100 \mathrm{~cm}^{-3}$ (Table 4). The ratio of the number of faecal coliforms to the total number of coliforms at sampling point 3 (on June) was higher than 0.7 , which indicates water contamination with animal faeces.

An additional indicator of microbiological quality of water is the total number of bacteria growing at temperature of $22^{\circ} \mathrm{C}$ (psychrophilic bacteria) and bacteria growing at temperature of $37^{\circ} \mathrm{C}$ (mesophilic bacteria). The total number of psychrophilic bacteria in the rainwaters varied from $<10$ to $1.9 \cdot 10^{4} \mathrm{cfu} \cdot \mathrm{cm}^{-3}$, while the number of mesophilic bacteria - from $<10$ to $5.1 \cdot 10^{3}$ $\mathrm{cfu} \cdot \mathrm{cm}^{-3}$ (Table 2). In $67 \%$ of cases, the numbers of psychrophilic and mesophilic bacteria exceeded the higher permissible defined for drinking water at the level of $100 \mathrm{cfu} \cdot \mathrm{cm}^{-3}$ and $50 \mathrm{cfu} \cdot \mathrm{cm}^{-3}[\mathrm{~J}$. of Laws 2007 No. 61, otem 417; J. of Laws 2010 No. 72 , item 466]. In February, in all analysed samples, the numbers of psychrophilic and mesophilic bacteria did not exceed the normative level.

According to Berleć et al. [2009], a value of the ratio of total number of psychrophilic bacteria to that of mesophilic bacteria higher than 10 permits to approximately classify water as pure. Applying that index, waters sampled from the pumping station can be classified as pure, except for the sample from February, and for the sample from tank I collected in September. In the remaining samples of water the ratio of the total number of psychrophilic to mesophilic bacteria varied from 0.49 to 7.31 , which indicates that the rainwaters collected from the roofs of the garage buildings at the Park Authority, RNP, contain anthropogenic contaminants.

The presented results indicate that in many cases the quality of the analysed rainwaters does not conform with the relevant standards. This is determined primarily by a high content of ammonia, manganese, and large numbers of indicator bacteria. It is worth noting, however, that the above analysis is based on rather rigorous criteria, laid down for drinking water, and does not disqualify the analysed waters from use for household purposes related with vehicle washing or irrigation of green areas.

Table 2. Numbers of indicator bacteria in rainwaters collected from roofs of garage buildings at Park Authority, RNP

\begin{tabular}{|c|c|c|c|c|c|c|c|c|c|c|c|c|}
\hline \multirow{3}{*}{ Parameter } & \multicolumn{12}{|c|}{ Sampling points } \\
\hline & \multicolumn{4}{|c|}{1} & \multicolumn{4}{|c|}{2} & \multicolumn{4}{|c|}{3} \\
\hline & II & $\mathrm{VI}$ & IX & $\mathrm{XI}$ & II & $\mathrm{VI}$ & IX & $\mathrm{XI}$ & II & $\mathrm{VI}$ & IX & $\mathrm{XI}$ \\
\hline $\begin{array}{l}\text { Coliform bacteria } \\
\text { MPN } \cdot 100 \mathrm{~cm}^{-3}\end{array}$ & $2.3 \cdot 10$ & $6.2 \cdot 10$ & $6.2 \cdot 10$ & 6 & 0 & $7 \cdot 10^{2}$ & $2.4 \cdot 10^{2}$ & 6 & 0 & $7 \cdot 10^{3}$ & $6.2 \cdot 10$ & 23 \\
\hline $\begin{array}{l}\text { Faecal coliforms } \\
\text { MPN } 100 \mathrm{~cm}^{-3}\end{array}$ & 0 & 6 & 0 & 0 & 0 & $2.1 \cdot 10$ & 0 & 0 & 0 & $7 \cdot 10^{3}$ & 0 & 0 \\
\hline $\begin{array}{l}\text { Psychrophilic } \\
\text { bacteria, } \\
\text { in } \mathrm{cfu} \cdot \mathrm{cm}^{-1}\end{array}$ & $<10$ & $1.3 \cdot 10^{4}$ & $5.5 \cdot 10^{3}$ & $1.6 \cdot 10^{3}$ & $1.8 \cdot 10$ & $9.3 \cdot 10^{3}$ & $2.9 \cdot 10^{3}$ & $1.9 \cdot 10^{2}$ & $<10$ & $1.9 \cdot 10^{4}$ & $8.4 \cdot 10$ & $6.7 \cdot 10^{2}$ \\
\hline $\begin{array}{l}\text { Mesophilic } \\
\text { bacteria, } \\
\text { in } \mathrm{cfu} \cdot \mathrm{cm}^{-1}\end{array}$ & $4 \cdot 10$ & $2.2 \cdot 10^{2}$ & $1.1 \cdot 10^{2}$ & $8 \cdot 10$ & $<10$ & $2.6 \cdot 10^{2}$ & $7 \cdot 10$ & $2.7 \cdot 10$ & $<10$ & $5.1 \cdot 10^{3}$ & $1.7 \cdot 10^{2}$ & $3.5 \cdot 10^{2}$ \\
\hline
\end{tabular}




\section{CONCLUSIONS}

1. The analysed rainwaters are characterised by good quality in terms of the content of mineral forms of nitrogen, phosphorus, sulphur, as well as of potassium and iron.

2. A probable cause of elevated levels of ammonia in the analysed waters was contamination of the roof surfaces with bird droppings.

3 . The alkaline reaction of the waters may indicate pollution of atmospheric air and of the roof surfaces with dusts from local stoves, and an effect of contaminants of animal origin.

4. The large numbers of coliforms, faecal coliforms, as well as meso- and psychrophilic bacteria are a symptom of contamination of the analysed rainwaters with animal faeces, washed off the roofs during rainfalls.

5. In terms of the microbiological indices and certain chemical indices, the analysed rainwaters are not suitable for drinking nor for hygiene purposes, but can be used for vehicle washing, irrigation of green areas, or for toilet flushing.

6. More extensive use of rainwaters for various household or economic purposes can significantly reduce water uptake and contribute to the protection of underground water resources in the area of the Roztocze National Park.

\section{REFERENCES}

1. Berleć K., Jurek A., Michalska M., Traczykowski A. 2009. Mikroflora rekultywowanych zbiorników wodnych na przykładzie Jeziora Rudnickiego Wielkiego. Rocznik Ochrona Środowiska, 11, 1029-1040.

2. Donaldson J. 1987. The physiopathologic significance of manganese in brain: its relation to schizophrenia and neurodegenerative disorders, Neuro Toxicology, 8, 451-462.

3. Funes A., De Vicente J., Cruz-Pizarro L., De Vicente I. 2014. The influence of $\mathrm{pH}$ on manganese removal by magnetic microparticles in solution, Water Research, 53, 110-122.

4. GUS (Central Statistical Office) 2015. Ochrona Środowiska. Informacje i opracowania statystyczne. Warszawa.

5. Hermanowicz W., Dojlido W., Dożańska W., Koziorowski B., Zerbe J. 1999. Fizykochemiczne badanie wody i ścieków. Arkady, Warszawa.

6. http://roztoczanskipn.pl/pl/

7. Jóźwiakowski K., Marzec M., Słowik T., Wałęga A., Krzanowski S., Skwarzyńska A., Pieńko A. 2013. Koncepcja budowy instalacji do wykorzystania wód opadowych w Dyrekcji Roztoczańskiego Parku Narodowego wraz ze wstępnym szacunkiem kosztów. Maszynopis. Katedra Inżynierii Kształtowania Środowiska i Geodezji, Uniwersytet Przyrodniczy w Lublinie.

8. Komisja Europejska (European Commission), Dyrekcja Generalna ds. Środowiska Naturalnego. 2011. Woda to życie. W jaki sposób Ramowa Dyrektywa Wodna chroni zasoby wodne Europy. Urząd Publikacji Unii Europejskiej, Luksemburg.

9. Królikowska J., Królikowski A. 2012. Wody opadowe. Odprowadzanie, zagospodarowanie, podczyszczanie i wykorzystanie. Wyd. Seidel-Przywecki Sp. z o.o., Warszawa.

10. Mańkowska-Wróbel L. 2014. Podstawowe problemy gospodarowania wodami opadowymi i roztopowymi na terenach zurbanizowanych. Prace Naukowe Akademii im. Jana Długosza w Częstochowie. Pragmata Tes Oikonomias, 8, 209-220.

11. Mazur T., Wojtas A. 1983. Zawartość suchej masy i makroskładników w pomiocie drobiowym. Roczniki Gleboznawcze, XXXIV, 3, 113-120.

12. Molenda T. 2006. Dynamika zmian wybranych zanieczyszczeń w spływach powierzchniowych zlewni zurbanizowanej. Infrastruktura i Ekologia Terenów Wiejskich, 4/3, 117-124.

13. Niemiec M. 2012. Zawartość wapnia, magnezu, sodu, fosforu i potasu w wodzie spływającej $\mathrm{z}$ dachów o różnych pokryciach. Proceedings of EC Opole, 6 (2), 763-767.

14. Ociepa E., Kisiel A., Lach J., 2010: Zanieczyszczenia wód opadowych spływających do systemów kanalizacyjnych. Proceedings of ECOpole, 4, 2, 466.

15. PN-C-04615-05:1975P. Woda i ścieki. Badania mikrobiologiczne. Oznaczenie bakterii grupy coli metodą fermentacyjną probówkową.

16. PN-C-04615-07:1977P. Woda i ścieki. Badania mikrobiologiczne. Oznaczenie bakterii grupy coli typu kałowego (fekalnego) metodą fermentacyjną probówkową.

17. PN-ISO 6222:1999. Jakość wody. Oznaczanie żywych mikroorganizmów. Określanie ogólnej liczy kolonii na agarze odżywczym metodą posiewu powierzchniowego lub wgłębnego.

18. Rozporządzenie Ministra Zdrowia z dnia 20 kwietnia 2010 r. zmieniające rozporządzenie w sprawie jakości wody przeznaczonej do spożycia przez ludzi (Dz.U. 2010 nr 72, poz. 466). 
19. Rozporządzenie Ministra Zdrowia z dnia 29 marca 2007 r. w sprawie jakości wody przeznaczonej do spożycia przez ludzi (Dz.U. 2007 nr 61, poz. 417).

20. Rybicki S. A., Rybicki S. M. 2001. Odprowadzanie i oczyszczanie wód deszczowych w strefach ochronnych ujęć wody. Ochrona środowiska, 1(80), 3-8.

21. Skwarzyńska A., Jóźwiakowski K., Marzec M., Pytka A., Gizińska M., Sosnowska B. 2014a. Wody opadowe w gospodarstwie domowym. Wodociągi - Kanalizacja, 2, 24-27.

22. Skwarzyńska A., Jóźwiakowski K., Sosnowska B., Pytka A., Marzec M., Gizińska M., SzyszlakBargłowicz J., Słowik T., Zając G. 2014b. Jakość wód opadowych i ocena możliwości ich wykorzystania $\mathrm{w}$ indywidualnych gospodarstwach domowych. Technologia Wody, 6 (38), 20-23.
23. Takeda A. 2003. Manganese action in brain function. Brain Res. Rev., 41(1), 79-87.

24. Tekerlekopoulou A.G., Vayenas D.V. 2008. Simultaneous biological removal of ammonia, iron and manganese from potable water using a trickling filter. Biochemical Engineering Journal, 39(1), 215-220.

25. Ustawa z dnia 18 lipca 2001 r. Prawo wodne (Dz. U. $2001 \mathrm{nr} 11$, po. 1229).

26. Ustawa z dnia 27 kwietnia 2001 r. Prawo ochrony środowiska (Dz. U. $2001 \mathrm{nr} 62$, poz. 627).

27. Wojtyła-Buciora P., Marcinkowski J. T. 2010. Szacowanie ryzyka zdrowotnego wynikającego z występowania przekroczeń parametrów chemicznych w wodzie przeznaczonej do spożycia. Problemy Higieny i Epidemiologii 91, 1, 137-142.

Pracę dofinansowano ze środków Wojewódzkiego Funduszu Ochrony Środowiska i Gospodarki Wodnej w Lublinie. 